\title{
Photodynamic Inactivation of plant pathogens part II: fungi
}

\author{
Christoph Hamminger ${ }^{1} \cdot$ Michael Glueck ${ }^{1}$ Michael Fefer ${ }^{2}$ - Wenzi Ckurshumova ${ }^{2}$. Jun Liü ${ }^{2} \cdot$ Raimund Tenhaken $^{3}$. \\ Kristjan Plaetzer ${ }^{1}$ (1)
}

Received: 28 September 2021 / Accepted: 9 December 2021 / Published online: 19 January 2022

(c) The Author(s) 2022

\begin{abstract}
The constantly increasing demand for agricultural produce from organic and conventional farming calls for new, sustainable, and biocompatible solutions for crop protection. The overuse of fungicides leading to contamination of both produce and environment and the emergence of plant pathogenic fungi that are resistant to conventional treatments warrant the need for new methods to combat fungal infections in the field. We here deliver the follow-up study to our research on the Photodynamic Inactivation (PDI) of plant pathogenic bacteria (Glueck et al. in Photochem Photobiol Sci 18(7):1700-1708, 2019) by expanding the scope to fungal pathogens. Both fungal species employed in this study-Alternaria solani and Botrytis cinerea - cause substantial crop and economic losses. Sodium magnesium chlorophyllin (Chl, approved as food additive E140) in combination with $\mathrm{Na}_{2}$ EDTA and the chlorin e6 derivative B17-0024 holding cationic moieties serve as eco-friendly photoactive compounds. Effectiveness of the antifungal PDI was measured by inhibition of growth of mycelial spheres (average diameter 2-3 mm) after incubation with the photosensitizer for $100 \mathrm{~min}$ and subsequent illumination using a LED array $\left(395 \mathrm{~nm}, 106.6 \mathrm{~J} \mathrm{~cm}^{-2}\right)$. One hundred micromolar Chl combined with $5 \mathrm{mM} \mathrm{Na}_{2}$ EDTA was able to successfully photokill $94.1 \%$ of $A$. solani and $91.7 \%$ of B. cinerea samples. PDI based on B17-0024 can completely inactivate A. solani at 10 times lower concentration $(10 \mu \mathrm{M})$; however, for $B$. cinerea, the concentration required for complete eradication was similar to that of Chl with $\mathrm{Na}_{2}$ EDTA $(100 \mu \mathrm{M})$. Using a plant compatibility assay based on Fragaria vesca, we further demonstrate that both photosensitizers neither affect host plant development nor cause significant leaf damage. The plants were sprayed with $300 \mu \mathrm{L}$ of treatment solution used for PDI (one or three treatments on consecutive days) and plant growth was monitored for 21 days. Only minor leaf damage was observed in samples exposed to the chelators $\mathrm{Na}_{2} \mathrm{EDTA}$ and polyaspartic acid, but overall plant development was unaffected. In conclusion, our results suggest that sodium magnesium chlorophyllin in combination with EDTA and B17-0024 could serve as effective and safe photofungicides.
\end{abstract}

Kristjan Plaetzer

kristjan.plaetzer@plus.ac.at

1 Laboratory of Photodynamic Inactivation of Microorganisms, Department of Biosciences and Medical Biology, Paris Lodron University of Salzburg, Hellbrunnerstr. 34, Salzburg, Austria

2 Suncor AgroScience, 2489 North Sheridan Way, Mississauga, ON L5K1A8, Canada

3 Plant Physiology, Department of Environment and Biodiversity, University of Salzburg, Hellbrunnerstr. 34, Salzburg, Austria 


\section{Graphical abstract}

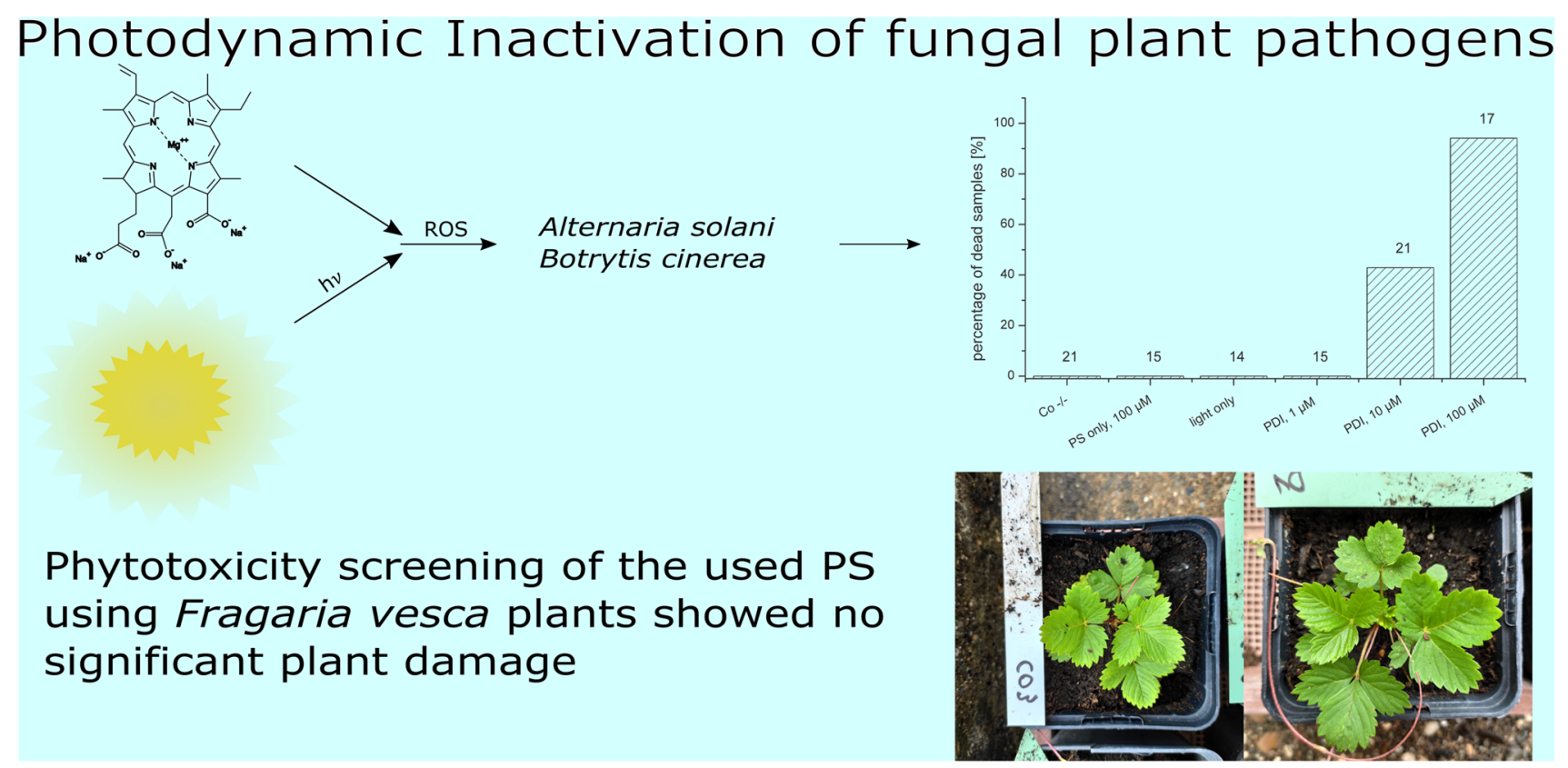

\section{Abbreviations}

$\begin{array}{ll}\begin{array}{l}\text { A. solani } \\ \text { B. cinerea }\end{array} & \text { Alternaria solani } \\ \text { CFU } & \text { Cotrytis cinerea } \\ \text { DCFDA } & \text { 2',7'-Dichlorofluorescin diacetate } \\ \text { DPBS } & \text { Dulbecco's phosphate-buffered saline } \\ \text { PDI } & \text { Photodynamic Inactivation } \\ \text { PS } & \text { Photosensitiser } \\ \text { ROS } & \text { Reactive oxygen species } \\ \text { PA } & \text { Polyaspartic acid } \\ \text { Na } 2 \text { EDTA } & \text { Ethylenediaminetetra-acetic acid diso- } \\ & \text { dium salt dihydrate } \\ \text { Chl } & \text { Sodium magnesium chlorophyllin } \\ \text { Chl-CHS } & \text { Chlorophyllin-chitosan } \\ \text { B17-0024 } & \text { B17-0024 Ce6-15,17-DMAE } \\ \text { Cu } & \text { Copper } \\ \text { Ce6 } & \text { Chlorin e6 } \\ \text { SOSG } & \text { Singlet oxygen sensor green } \\ \text { S. lycopersicum } & \text { Solanum lycopersicum } \\ \text { F. vesca } & \text { Fragaria vesca } \\ \text { EPPO } & \text { European and Mediterranean Plant Pro- } \\ & \text { tection Organization } \\ \text { PDI-PCA } & \text { PDI-plant compatibility assay }\end{array}$

\section{Introduction}

Since the industrial revolution, our society must cope with an ever-growing world population on one hand and a decline in available arable land per person on the other hand $[1,2]$. The rising need for food in industrialised countries has mainly been satisfied by high-density industrial monocultures. According to the American Phytopathological Society, the global production of tomato was about 159 million tons and the production of potato 375 million tons in 2011 [3]. However, industrialized farming poses the risk of high crop losses in the case of disease outbreaks or pest infestations and overuse of pesticides comes at a high cost for the environment. Phytopathogenic fungi have the potential to spread by air, animals, contaminated soil or water and therefore have the potential to obliterate entire harvests. This situation is further aggravated by the rise of resistant fungal strains.

The list of fungal species that trouble growers is extensive. Two phytopathogens, Altanaria solani (causing early blight in Solanum lycopersicum, tomato) and Botrytis cinerea (responsible for grey mold) are among the top threats as they affect important and valuable crops. Altanaria solani is responsible for estimated $78 \%$ of annual financial tomato yield losses [4]. Early blight symptoms include lesions on aboveground organs that as disease progresses may result in complete defoliation of infected plants [5]. Botrytis cinerea is able to infect about 200 different plant species and causes financial damage of 10-100 billion USD per year [6] with grapevines representing the most important host for the pathogen where it induces grey rot/mold and noble rot. Other target crops with severe outcomes are e.g.: strawberry, raspberry and vegetables like broccoli or lettuce. Both fungi are considered necrotrophic as they sustain themselves of nutrients from dead plant tissue. 
As current management strategies in conventional farming for infections with A. solani, the EPPO recommends the use of anilazine, azoxystrobin, chlorothalonil, $\mathrm{Cu}$ compounds, cymoxanil, difenoconazole, famoxadone, oxadixyl, procymidone in their EPPO Standards for good plant protection practice for solanaceous crops under protected cultivation [7] and azoxystrobin, chlorothalonil, copper, difenoconazole, famoxadone, iprodione, procymidone, tolylfluanid for outdoor crops [8].

In case of organic farming, copper compounds are widely used to fight fungal disease. Kuehne et al. [9] estimate the amount of copper compounds used in German conventional apple farming in the year 2013 to $1.4 \mathrm{~kg} \mathrm{ha}^{-1}$, and, nearly identical, to $1.5 \mathrm{~kg} \mathrm{ha}^{-1}$ in organic farming. However, in other crops, e.g. grapes, the usage of copper compounds increases from 0.8 in conventional agricultural farming to $2.29 \mathrm{~kg} \mathrm{ha}^{-1}$ in organic farming. In total, $84.4 \mathrm{t}$ of copper compounds were applied in conventional farming and $26.5 \mathrm{t}$ in organic farming [9]. This massive input of copper-natural $\mathrm{Cu}$ concentrations range from 20 up to $100 \mathrm{mg} \mathrm{Cu} \mathrm{kg}^{-1}$ soil depending on soil type [10, 11] may lead to accumulation in the environment: data from vineyards in France prove that concentrations up to $1500 \mathrm{mg} \mathrm{Cu} \mathrm{kg}^{-1}$ soil can be reached [12]. This accumulation of Copper in the soil can have toxic effects on the microbiome, groundwater and plants [13]. Although considered controversial, the European Commission extended the approval of copper compound usage (up to $28 \mathrm{~kg} \mathrm{Cu}$ $\mathrm{ha}^{-1}$ ) until 2025 as stated in the Commission implementing regulation (EU) 2018/1981 of 13 December 2018 [14], as effective and sparing alternatives are lacking.

Photodynamic Inactivation (PDI) utilizes photosensitizer molecules (PS) that when activated by light produce reactive oxygen species that can rapidly oxidize multiple cellular targets resulting in nearly instantaneous pathogen cell death. Advantages of PDI include no known resistance and the broad range of pathogens that can be targeted [15]. To determine the ROS and/or singlet oxygen production capabilities of the used PS system we performed a DCFDA and SOSG assay.

The objective of this study is to assess the utility of two chlorin PS previously shown to have great efficacy against bacterial plant pathogens [16]. We use the anionic watersoluble semi synthetic chlorophyll derivative sodium magnesium chlorophyllin (Chl; registered as food additive E140) combined with a chelator (Ethylenediaminetetra-acetic acid disodium salt dihydrate, $\mathrm{Na}_{2}$ EDTA) and the chlorin e6 derivative B17-0024 Ce6-15,17-DMAE (B17-0024), carrying cationic moieties (kindly provided by Suncor AgroScience), as PS. In addition we examine the effects of PDI on strawberry leaves under natural sunlight in two application scenarios:"type S"-similar to applications in the field, or "type T"-maximizing the amount of PS delivered to the foliage to assess the potential effect of PDI treatment on the host plant.

\section{Experimental}

\subsection{Preparation of stock solutions}

Sodium magnesium chlorophyllin (Chl, Carl Roth $\mathrm{GmbH}+\mathrm{Co}$. KG, Karlsruhe, Germany) and B17-0024 (kindly provided by Suncor AgroScience, Mississauga Ontario, Canada) were dissolved in ultrapure water to get stock solutions with $10 \mathrm{mM}$ PS concentration and stored at $-20{ }^{\circ} \mathrm{C}$ in the dark until use. Polyaspartic acid (PA; Baypure ${ }^{\circledR D S} 100$; Kurt Obermeier GmbH \& Co. KG, BadBerleburg, Germany) was acquired as $40 \%$ solution. A solution of $400 \mathrm{mM} \mathrm{Na} 2$ EDTA (EDTA disodium salt dihydrate, VWR International, B-3001 Leuven) was obtained by dissolving in ultrapure water, adjusting the $\mathrm{pH}$ to 7.8 and subsequent autoclaving. All solutions for the plant compatibility assays were prepared using tap water.

\subsection{ROS and singlet oxygen detection}

For the measurement of the absorption spectra of Chl, Chl with $5 \mathrm{mM} \mathrm{Na}_{2}$ EDTA or B17-0024 (PS concentration $100 \mu \mathrm{M}$ in DPBS) $100 \mu \mathrm{l}$ were transferred into a 96 well plate ( $\mu$-clear, Greiner Bio-One GmbH, Kremsmünster, Austria). The absorption signal was measured using a Infinite M200 microplate reader (Tecan, Grödig, Austria). To detect the singlet oxygen generation the Singlet Oxygen Sensor Green (Invitrogen by Thermo Fisher Scientific) assay was perfomed. Ninety microliters of $\mathrm{Chl}(100 \mu \mathrm{M})$, Chl $(100 \mu \mathrm{M})$ with $5 \mathrm{mM} \mathrm{Na}{ }_{2}$ EDTA orB17-0024 $(100 \mu \mathrm{M})$ were mixed with $10 \mu \mathrm{M}$ SOSG (stock solution $500 \mu \mathrm{M}$ in $100 \%$ methanol kept on ice until use) and illuminated for up to $1 \mathrm{~J} \mathrm{~cm}^{-2}$ at $395 \mathrm{~nm}$ (irradiance $8 \mathrm{~mW} \mathrm{~cm}{ }^{-2}$ measured with a LI-180 Spectrometer, LI-COR Biosciences GmbH, Bad Homburg, Germany) in a 96 well plate ( $\mu$-clear, Greiner Bio-One $\mathrm{GmbH}$ ). Additionally the production of reactive oxygen species (ROS) was investigated using 2',7'-Dichlorofluorescin diacetate (DCFDA, Sigma-Aldrich Handels GmbH, Wien, Austria). The $10 \mathrm{mM}$ DCFDA stock was prepared in DMSO. Fifty microliters of dissolved DCFDA were mixed with $200 \mu \mathrm{l}$ of $10 \mathrm{mM}$ sodium hydroxide and incubated in the dark at room temperature for $30 \mathrm{~min}$ to form dichlorofluorescin (DCFH). After the incubation period, $1 \mathrm{ml}$ of DPBS buffer was added to neutralize the solution. The DCFH solution was kept on ice until use. [17] DCFH $(10 \mu \mathrm{M})$ was mixed with $100 \mu \mathrm{M}$ PS (with and without $5 \mathrm{mM} \mathrm{Na}_{2}$ EDTA for $\mathrm{Chl}$ ). Ninety microliters of the mixture were placed in a single well of a 96 well plate ( $\mu$-clear, Greiner Bio-One $\mathrm{GmbH}$ ) and subsequently illuminated at $395 \mathrm{~nm}$ for up to 
$1 \mathrm{~J} \mathrm{~cm}^{-2}$. The fluorescence of the illuminated SOSG and DCFH samples was measured using an Infinite M200 microplate reader with excitation wavelength $488 \mathrm{~nm}$ and emission wavelength $525 \mathrm{~nm}$. The gain was set to 70 .

\subsection{Fungal culture}

Botrytis cinerea was grown on agar plates containing $30 \mathrm{~g}^{-1}$ malt extract (Roth), $3 \mathrm{~g} \mathrm{l}^{-1}$ peptone (Peptone ex casein, Roth) and $15 \mathrm{~g} \mathrm{l}^{-1}$ Agar-Agar (Kobe I, Roth) at $26{ }^{\circ} \mathrm{C}$. Spores were transferred from the plates into liquid medium and incubated at $26{ }^{\circ} \mathrm{C}$ and $200 \mathrm{rpm}$ in a shaking incubator (MaxQ 4000, Thermo Scientific, Marietta Ohio, USA) for $48 \mathrm{~h}$ to obtain spherical patches of mycelia with an average diameter of 1-2 $\mathrm{mm}$. Alternaria solani was grown on agar plates containing $200 \mathrm{ml} \mathrm{l}^{-1}$ tomato mash (Passata di Pomodoro, S Budget, Spar Österreichische WarenhandelsAG, Salzburg, Austria), $3 \mathrm{~g}^{-1} \mathrm{CaCO}_{3}$ (Sigma-Aldrich Chemie $\mathrm{GmbH}$, Steinheim, Germany) and $15 \mathrm{~g} \mathrm{l}^{-1}$ Agar-Agar (Roth) at $26^{\circ} \mathrm{C}$ for 3-4 days. Parts of the mycelium from the edge of the growing mycelial disc were transferred to liquid medium and incubated at $26^{\circ} \mathrm{C}$ under constant agitation at $200 \mathrm{rpm}$ for $24 \mathrm{~h}$ in a shaking incubator to obtain mycelial spheres of approximately $2 \mathrm{~mm}$ diameter.

\subsection{PDI of B. cinerea and A. solani}

Mycelial spheres were transferred into 24-well plates (one per well) using a pipette. Five hundred microliters of DPBS containing no PS (double negative control, Co -/-, light only) or either $1 \mu \mathrm{M}, 10 \mu \mathrm{M}$ or $100 \mu \mathrm{M}$ of the respective photoactive compound were added to the wells. The samples were incubated for $100 \mathrm{~min}$ in the dark at room temperature under constant agitation and subsequently illuminated from below using a LED array (irradiance $14.8 \mathrm{~mW} \mathrm{~cm}^{-2}$, radiant exposure $106.6 \mathrm{~J} \mathrm{~cm}^{-2}$ ) consisting of 432 light emitting diodes (diode type L-7113UVC, dominant wavelength 395 nm, Kingbright Electronic Europe GmbH, Issum, Germany). After illumination, the mycelial spheres were carefully transferred to tomato mash agar plates (A. solani) or malt peptone agar plates $(B$. cinerea) to evaluate the photokilling efficiency. Samples showing no growth after 7 days of incubation at $26{ }^{\circ} \mathrm{C}$ were considered as dead. The percentage of dead mycelial spheres was calculated by dividing the number of dead samples by the number of treated samples (multiplied by 100).

\subsection{PDI-plant compatibility assay}

To assess possible damage of the compounds employed in this study (B17-0024 [Ce6 15, 17, DMAE], Chl and PA/Na ${ }_{2}$ EDTA) to the host plant a PDI-plant compatibility assay as shown in Fig. 1 was established [18]. Fragaria vesca (small woodland strawberry) was chosen as model plant. Fragaria vesca is a high value crop susceptible to various fungal pathogens that can cause economically devastating disease outbreaks [19]. The foliage is pale green, which allows for easy evaluation of damage. Fragaria vesca seeds (indigenous to Salzburg, Austria) were obtained from the seed collection of the botanical garden (Paris Lodron University of Salzburg) and germinated in a greenhouse (temperature range: $\min 18^{\circ} \mathrm{C}, \max 43^{\circ} \mathrm{C}$, 50-70\% rel. humidity) using CL ED73 "Einheitserde" (> 50\% white peat, $\sim 30 \%$ clay, $20 \%$ block peat [20]) as plant substrate. The plants were not additionally fertilized. The seedlings were later pricked out to individual pots and subsequently transferred outside under a transparent rain cover (mean temp. $16^{\circ} \mathrm{C}$ ). The plants were grown up to $\mathrm{BBCH}$ stage 14 and all runners were pruned to ensure a comparable experimental baseline. Plants that showed

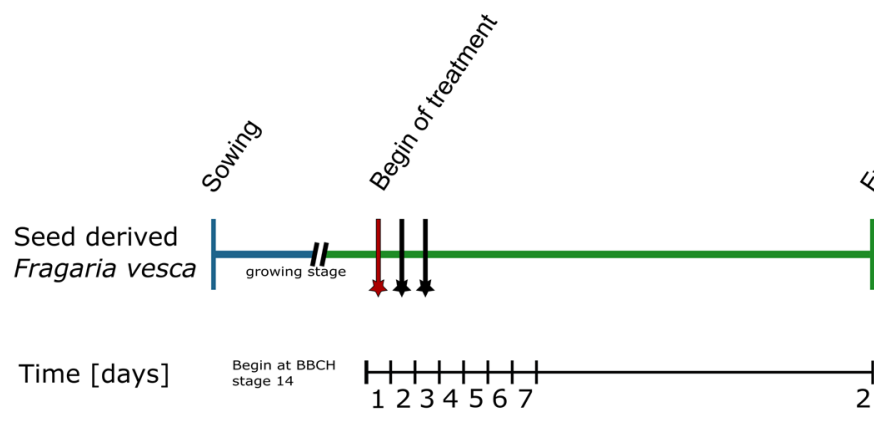

Fig. 1 Schematic timeline of the PDI-plant compatibility assay on Fragaria vesca. Blue line: plants were grown inside a greenhouse. Green line: plants were grown outside under a transparent rain cover. Red star: start of treatment for type $\mathrm{S}$ (treated one time) and type $\mathrm{T}$ (treated three times); black stars: treatment days for the three times treated samples (type T). Evaluation was done at day 21 after BBCH14 

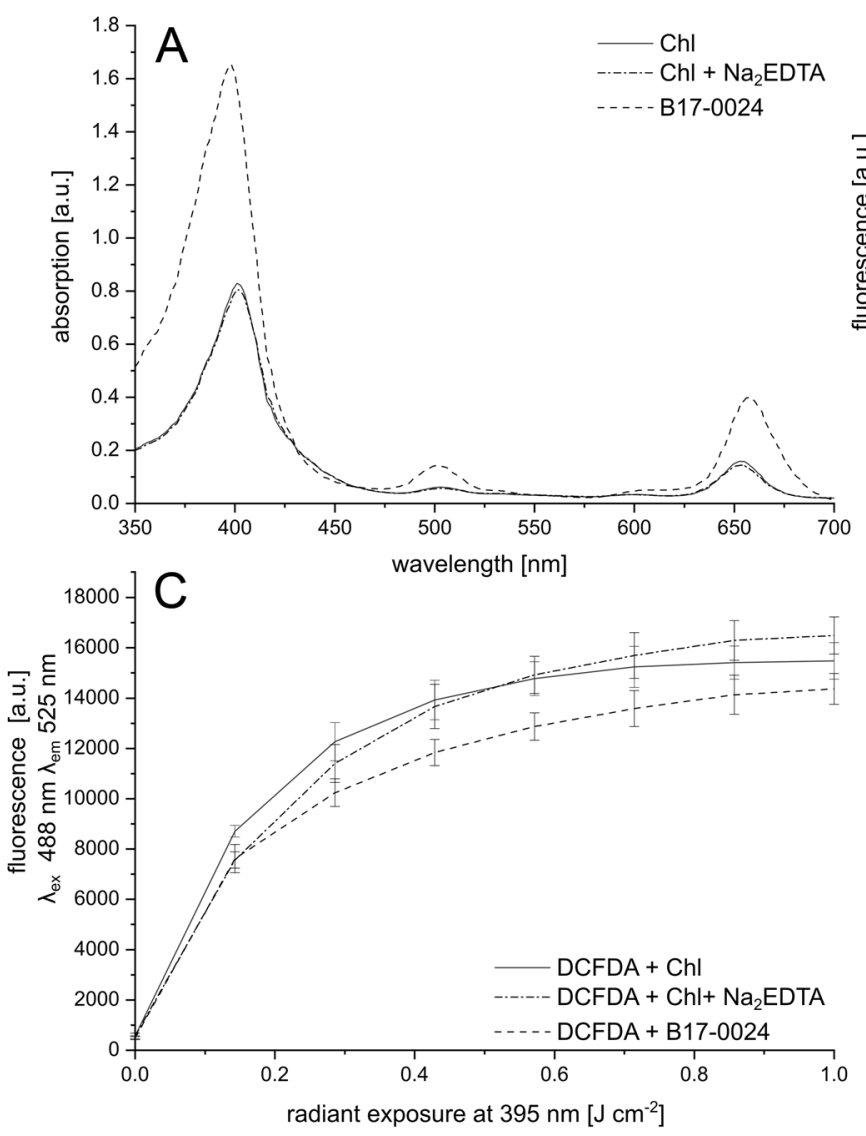

Fig. 2 Photophysical properties of the photosensitizers and PS mixtures used in this study. Straight line: Chl, dash-dot: $\mathrm{Chl}+\mathrm{Na}_{2}$ EDTA, dashed line: B17-0024. A Absorption specta Chl, Chl+5 mM $\mathrm{Na}_{2}$ EDTA and B17-0024 (PS concentration for all samples $100 \mu \mathrm{M}$, measured in triplets). B and C SOSG and DCFDA assay of Chl $(100 \mu \mathrm{M})$, Chl $(100 \mu \mathrm{M})+\mathrm{Na}_{2}$ EDTA $(5 \mathrm{mM})$ and B17-0024

signs of pest damage before the first treatment were removed from the experiment. Two different application methods were evaluated: "type S", a single treatment and "type T", a total of three treatments on subsequent days, aiming to maximize exposure of plant foliage to the PS. Samples were divided into the following test groups: (1) $\mathrm{H}_{2} \mathrm{O}$ - "type T", (2) $\mathrm{Na}_{2}$ EDTA-"type T", (3) Chl + $5 \mathrm{mM}$ $\mathrm{Na}_{2}$ EDTA- "type S", (4) Chl + $5 \mathrm{mM} \mathrm{Na}_{2}$ EDTA- "type T", (5) B17-0024-“type S" and (6) B17-0024-“type T" and one complete set where $\mathrm{Na}_{2}$ EDTA was replaced with a stronger chelating agent (Baypure DS $100 ®(\mathrm{PA})$ ). For each test group a total of four plants were used. Each plant was sprayed with $300 \mu \mathrm{L}$ of the respective solution from above according to the treatment regime. Plant health and growth was monitored and documented (Nikon D40, Objective: Nikon DX AF-S NIKKOR 18-55 mm 1.3.5-5.6 GII ED DSLR camera) for 21 days. After this period a qualitative plant compatibility evaluation according to the following parameters was performed: (1) leaf or plant
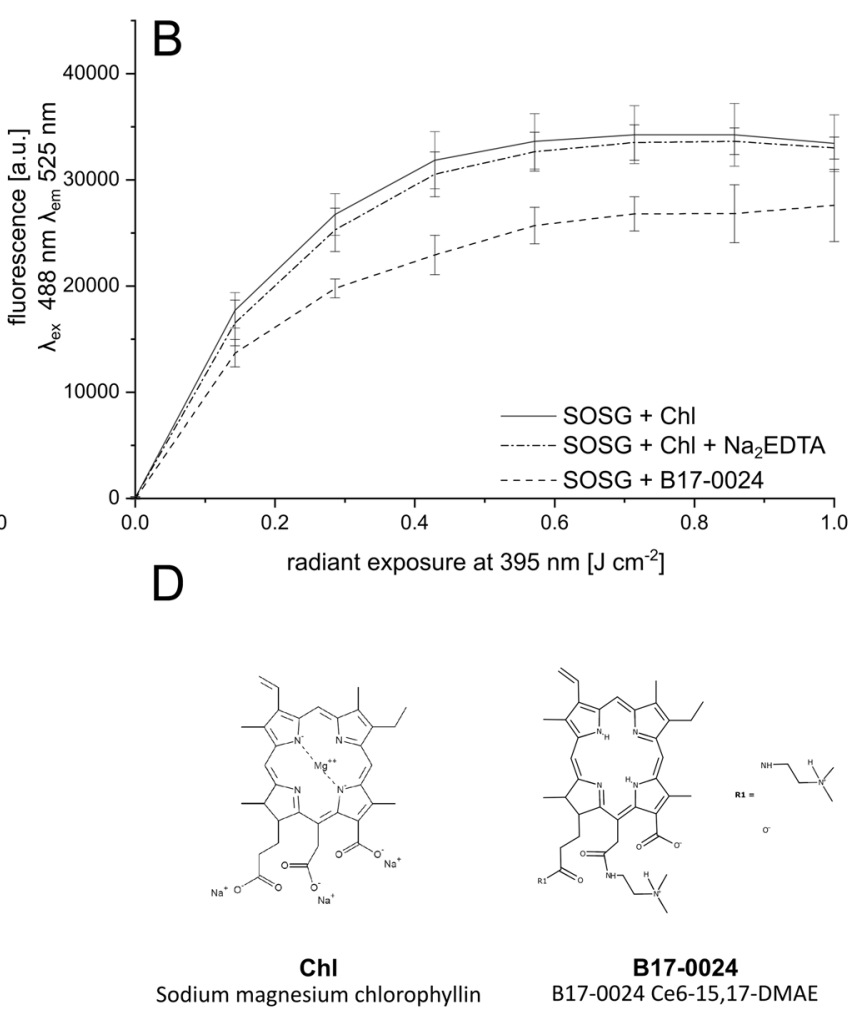

B17-0024
B17-0024 Ce6-15,17-DMAE

$(100 \mu \mathrm{M})$. Excitation $\left(\lambda_{\mathrm{ex}}\right) 488 \mathrm{~nm}$; emission $\left(\lambda_{\mathrm{em}}\right) 525 \mathrm{~nm}$, gain 70 . Illuminated up to $1 \mathrm{~J} \mathrm{~cm}^{-2}$ using a $395 \mathrm{~nm}$ LED array. The mean of three experiments is shown. D Chemical structure of Sodium magnesium chlorophyllin (Chl) and B170024 Ce6-15,17-DMAE (B170024)

death, (2) growth inhibition, (3) leaf deformations and (4) leaf discoloration as well as brown spots or leaf margins.

\section{Results and discussion}

This study is a continuation of our previous work published in Photochemical and Photobiological Sciences in 2019 [16] by extending the application spectrum of Photodynamic Inactivation with chlorin molecules from bacterial to fungal phytopathogens. We used sodium magnesium chlorophyllin (approved as food additive "natural green" E140) with and without $\mathrm{Na}_{2}$ EDTA and B17-0024, a synthetic derivative of Ce6 with cationic moieties without additives as photoactive compounds.

The absorption spectra (Fig. 2A) of both PS (Fig. 2D) show an absorption maximum at $398 \mathrm{~nm}$ for B17-0024 (absorption 1.66) and at $401 \mathrm{~nm}$ for Chl (absorption 0.83). The addition of $\mathrm{Na}_{2}$ EDTA does not alter the absorption 
spectrum of Chl (Fig. 2A) (absorption 0.81 at $401 \mathrm{~nm}$ ). At the same PS concentration $(100 \mu \mathrm{M})$ the absorption of B170024 is twice as high as the one of Chl. Upon illumination of a mixture of the PS with SOSG, SOSG turns fluorescent depending on the radiant exposure applied. Similar to the absorption spectrum - the addition of $\mathrm{Na}_{2}$ EDTA to Chl does not influence the SOSG fluorescence signal (Fig. 2B) and thus does not interfere with the photodynamic reaction. The SOSG fluorescence signal of B17-0024 is lower than the signal of Chl. The DCFDA assay leads to a similar outcome. The fluorescence signal increases with increasing radiant exposure (Fig. 2C). As expected $\mathrm{Na}_{2}$ EDTA does not influence the outcome of the assay. The results of both the SOSG and DCFDA assay suggest, that $\mathrm{Chl}$ and B17-0024 form singlet oxygen as well as ROS. According to the literature, chlorin-based PS tend to be characterized to function for the most part by the type II photochemical reaction [30-32]. The additive $\mathrm{Na}_{2}$ EDTA does not influence the photophysical processes of the photodynamic reaction.

For treatment of planktonic bacteria incubation with PS for 5 min was sufficient to achieve a more than $6 \log$ killing of pathogens. However, for antifungal activity, as small three-dimensional mycelial spheres were treated, the incubation period was extended to $100 \mathrm{~min}$ to allow for diffusion of the photosensitizers into the 3D structures and the radiant exposure was increased to $106.6 \mathrm{~J} \mathrm{~cm}^{-2}$ to ensure light saturation.

One key difference between bacteria and fungi relevant for the PDI photokilling process is the composition of fungal cell walls, which are comprised of mannan, glucan and chitin-the latter two form interchain hydrogen bonds and basically constitute the exoskeleton of the fungal cell-as well as proteins and further polysaccharides, depending on fungal species [21]. This structure and the larger size of fungal cells call for adjustments of the PDI treatment regime for fungi in comparison to bacteria. Both, the incubation period and the delivered light energy were increased for antifungal PDI.

As a result of this different cell wall composition, photoinactivation of $A$. solani (Fig. 3A) showed only a $11.5 \%$ killing and was ineffective against $B$. cinerea (Fig. 4A) when using the negatively charged $\mathrm{Chl}$ without cell wall permeabilizing agents. In contrast, $A$. solani was successfully photoinactivated with a killing efficiency of $94.1 \%$ when using $100 \mu \mathrm{M} \mathrm{Chl}$ in combination with $5 \mathrm{mM} \mathrm{Na}_{2}$ EDTA (Fig. 3B) and B17-0024 (Fig. 3C), which induced complete inactivation of the mycelia with (100\% killing) at concentrations of $10 \mu \mathrm{M}$ and above. The used photosensitizers (PS only, $100 \mu \mathrm{M}$ ) showed no signs of dark or light toxicity (light only) after $120 \mathrm{~min}$. Sample photographs of the experiment are shown in supplementary data (Figure S1).

Experiments using $B$. cinerea as model fungus resulted in very comparable photoinactivation. Again, $\mathrm{PDI}$ using $\mathrm{Chl}$ without additives (Fig. 4A) had no effect on fungal growth

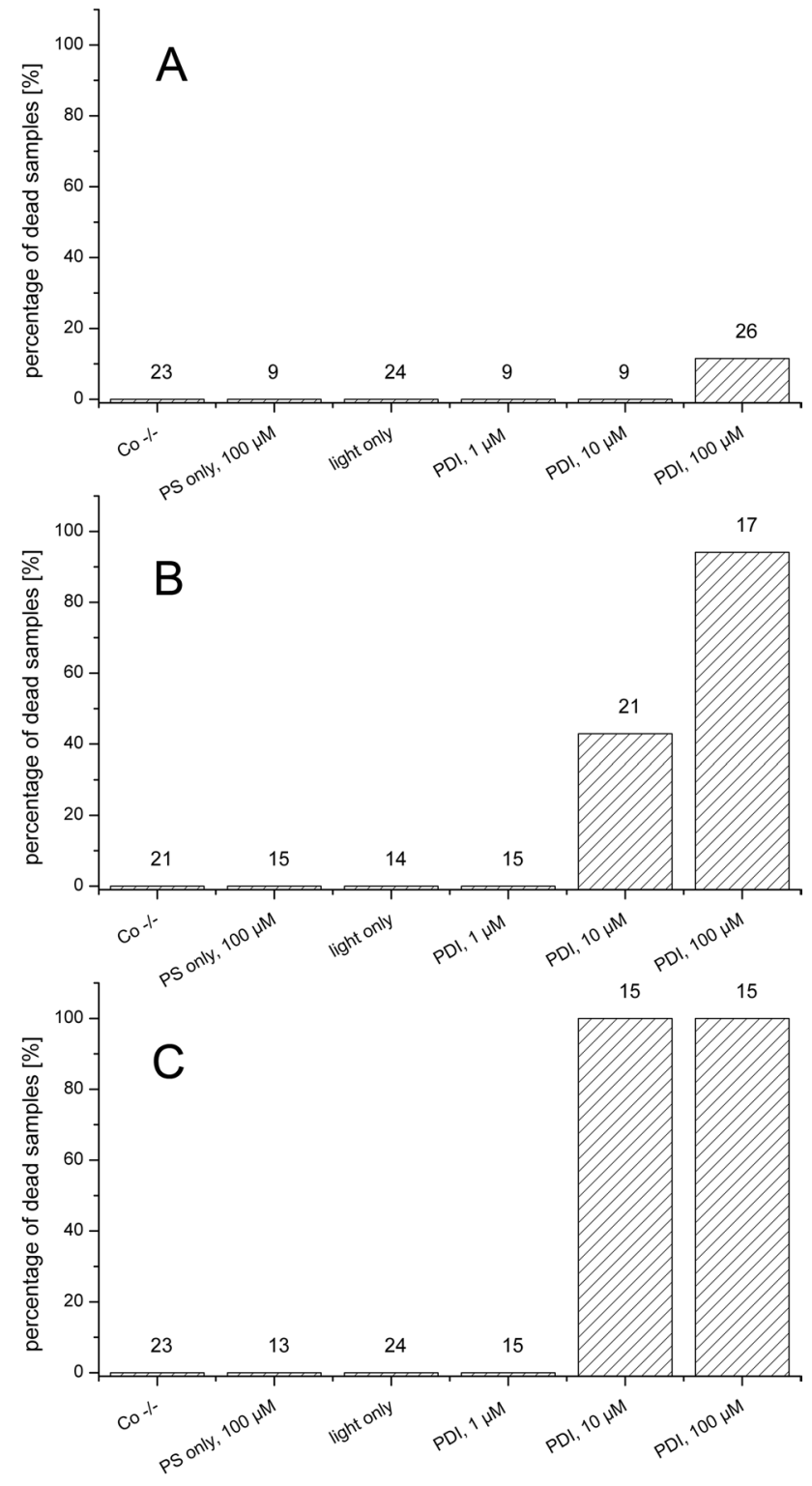

Fig. 3 Percentage of dead Alternaria solani samples after Photodynamic Inactivation using: A Chl, B Chl with $5 \mathrm{mM} \mathrm{Na} \mathrm{m}_{2}$ EDTA and C B17-0024 at concentrations of $1 \mu \mathrm{M}, 10 \mu \mathrm{M}$ and $100 \mu \mathrm{M}$. The samples were incubated for $100 \mathrm{~min}$ and subsequently illuminated for $120 \mathrm{~min} @ 395 \mathrm{~nm}$ (radiant exposure of 26.6. J/ $\mathrm{cm}^{2}$ ). The number above the bars indicates the number of treated samples. Co-/-, negative control; PS only, PS dark control; light only; PDI, PS + illumination

resulting in $100 \%$ viable samples. Combination of $10 \mu \mathrm{M}$ Chl with $5 \mathrm{mM}$ of $\mathrm{Na}_{2}$ EDTA induced photokilling of $33.3 \%$ and after increasing the concentration of Chl to $100 \mu \mathrm{M}$ (+ $5 \mathrm{mM} \mathrm{Na}_{2}$ EDTA) almost complete eradication (91.7\%) was achieved (Fig. 4B). B17-0024 was able to kill $66.7 \%$ of all samples at a concentration of $10 \mu \mathrm{M}$ and resulted in complete photokilling at $100 \mu \mathrm{M}$ (Fig. 4C). Once more, neither the photosensitizers, nor the activating light influenced the 


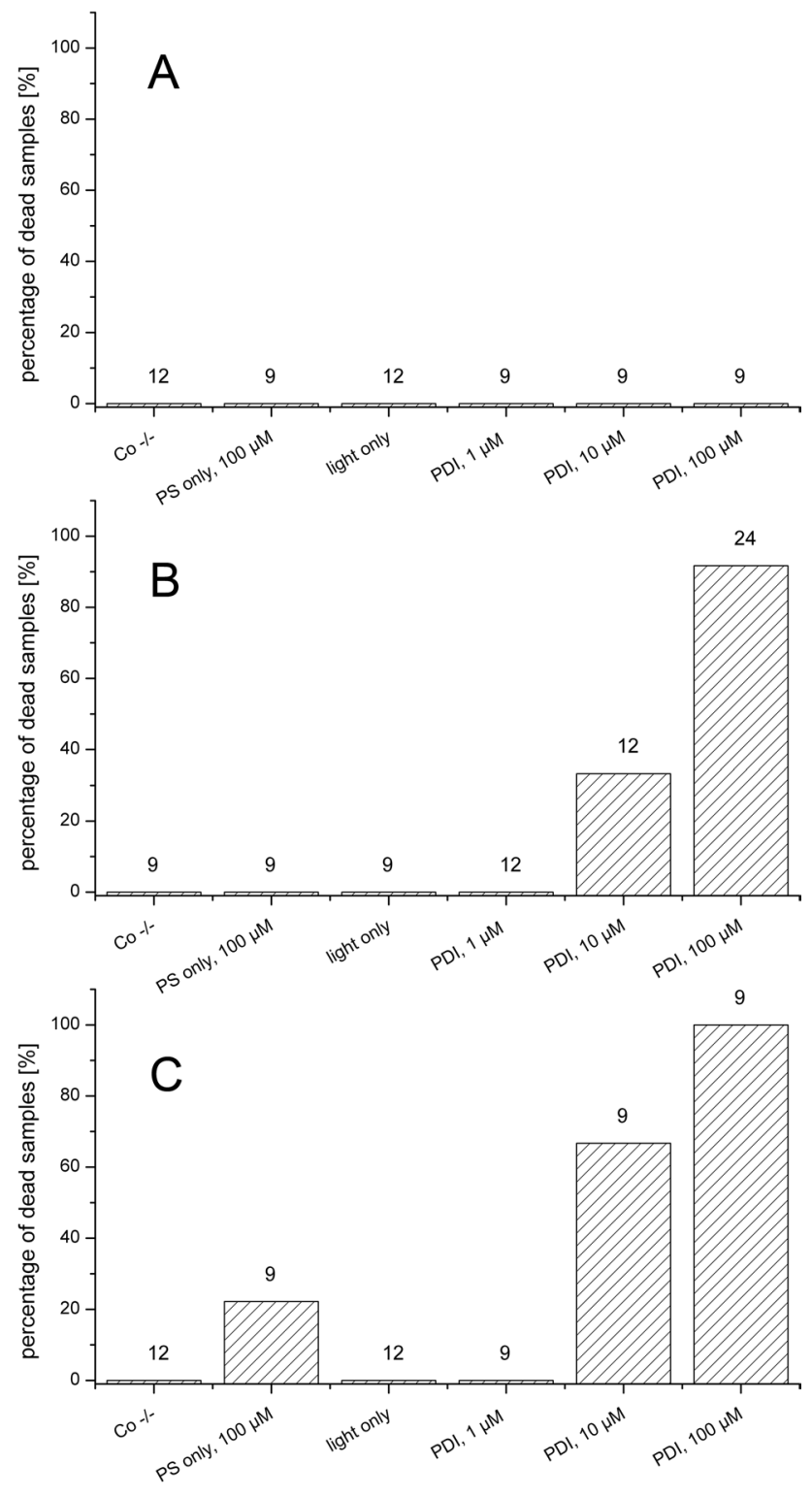

Fig. 4 Percentage of dead Botrytis cinerea samples after Photodynamic Inactivation using: A Chl, B Chl with $5 \mathrm{mM} \mathrm{Na}_{2}$ EDTA and C B17-0024 at concentrations of $1 \mu \mathrm{M}, 10 \mu \mathrm{M}$ and $100 \mu \mathrm{M}$. The samples were incubated for $100 \mathrm{~min}$ and subsequently illuminated for $120 \mathrm{~min} @ 395 \mathrm{~nm}$ (radiant exposure of $26.6 . \mathrm{J} / \mathrm{cm}^{2}$ ). The number above the bars indicates the sample size. Co-/-, negative control; PS only, PS dark control; light only; PDI, PS + illumination

growth of the mycelial patches. The photodocumentation of the experiment can be found in the supplementary data (Figure S1).

A different approach to treat bacteria and fungi with Chl was suggested by Luksiene and coworkers in 2011 [22]. The authors did not study the effects on plants but performed Chl-based PDI on strawberry fruits to extend the shelf life of the produce. After inoculation of the fruits with Listeria monocytogenes, incubation with $1 \mathrm{mM} \mathrm{Chl}$ for $5 \mathrm{~min}$ the illumination of the samples was performed using blue light ( $400 \mathrm{~nm}, 12 \mathrm{~mW} \mathrm{~cm}{ }^{-2}, 30 \mathrm{~min}$ ). By this, the shelf life of the strawberries was increased by two days [22].

To overcome the poor interaction of $\mathrm{Chl}$ with the fungal cell wall a Chlorophyllin-Chitosan (Chl-CHS) complex (0.001-0.1\%) was used for photokilling of Botrytis cinerea. Illumination at $405 \mathrm{~nm}$ with $38 \mathrm{~J} \mathrm{~cm}^{-2}$ resulted in up to $60 \%$ growth inhibition of the fungus [23].

Buchovec et al. [23], studied inactivation of naturally occurring yeasts/molds on the surface of strawberries by $1.4 \mathrm{log}$ achieved again based on the photoactivated Chl-CHS complex $\left(1.5 \times 10^{-5} \mathrm{M} \mathrm{Chl-0.1 \%} \mathrm{CHS}\right.$; incubated for $30 \mathrm{~min}$ and illuminated with $38 \mathrm{~J} \mathrm{~cm}^{-2}$ ).

EDTA has been shown to be an efficient cell membrane permeabilizer being able to aid the uptake of various molecules into the cell [24] and thus may facilitate improved delivery of the anionic PS in fungal cells. The higher efficacy of B17-0024 may be due to the cationic moieties facilitating its own entry into the cells, as previously shown for cationic porphyrins [25].

Chl and $\mathrm{Na}_{2}$ EDTA are readily available, can simply be mixed together without the need of complexation, and economic. This is especially of importance if the substances are applied in agriculture, where considerable amounts of PS and additives are needed to successfully photoinactivate entire fields or orchards. Chl is also registered as food additive E140 without upper limit in the European Union and shall therefore be easy to register as plant protection agent.

To exclude negative effects of PDI on host plants a phototreatment with the same PS was performed using a plant compatibility assay on woodland strawberries $(F$. vesca at growing stage BBCH14 [26]). All used PS as well as $\mathrm{Na}_{2}$ EDTA were tested in the same concentrations as in the fungal experiments described above. We also tested an alternative chelator PA (Baypure DS 100®) with higher chelation power for phytotoxic effects on leaves. To give a better overview, a comparison between representative samples (day 0 and day 21 for 2 plants per treatment group) is given in Figs. 5, 6 and 7. In Fig. 5, the results of the first PDIplant compatibility assay (PDI-PCA) are shown. B17-0024 (Type $\mathrm{S}$ and $\mathrm{T}$ treatment), $\mathrm{Chl}$ (type $\mathrm{S}$ and $\mathrm{T}$ ), $\mathrm{Na}_{2}$ EDTA (type T) and tap water (type T) were tested. In Fig. 5 only type $\mathrm{T}$ treatments are shown since the type $\mathrm{S}$ treatments did not result in any leaf damage, deformation or discolouration. The results of the PDI-PCA applying type T treatment showed no signs of leaf damage for B17-0024, Chl and the water control after 21 days but plant one in the $\mathrm{Na}_{2}$ EDTA test group $+21 \mathrm{~d}$ showed minimal deformations (arrows) in leaves which were in contact with the solutions containing $\mathrm{Na}_{2}$ EDTA. The photoactive compounds do not seem to have a negative effect on plant health and development per se, and the use of $\mathrm{Na}_{2}$ EDTA caused only minor leaf damage in one sample. 


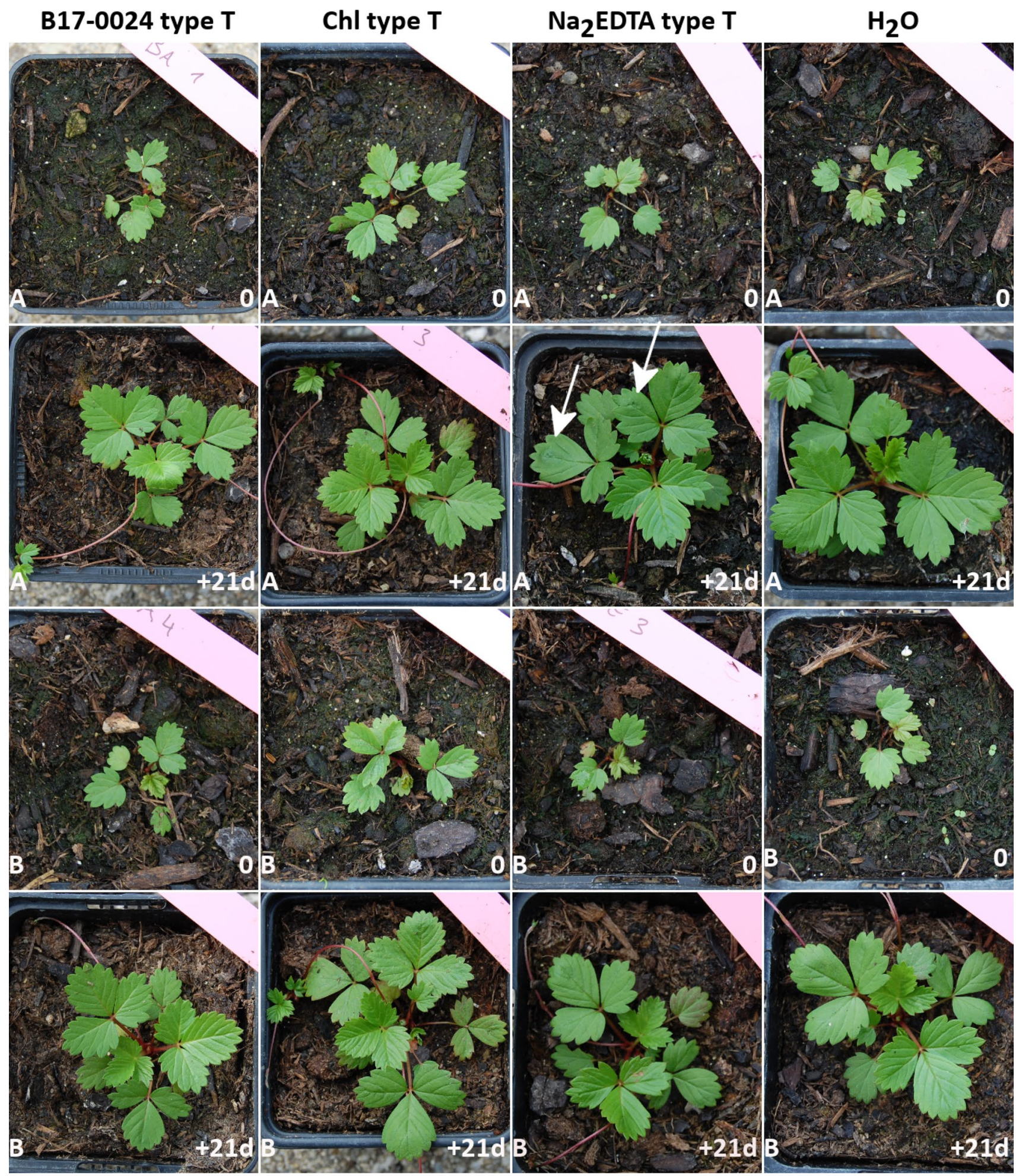

Fig. 5 PDI-plant compatibility assay on young Fragaria vesca plants. Two representative plants per treatment group as indicated with "A" and "B" at day zero indicated by " 0 " and 21 days after treatment start "+21d" are shown. Samples were sprayed (300 $\mu$ from above) three times (type T) with B17-0024, Chl or $\mathrm{H}_{2} \mathrm{O}$ (control) and $5 \mathrm{mM}$ $\mathrm{Na}_{2}$ EDTA (chelator only). Leaf damage sites or deformations are indicated by arrows 


\section{PA type T}
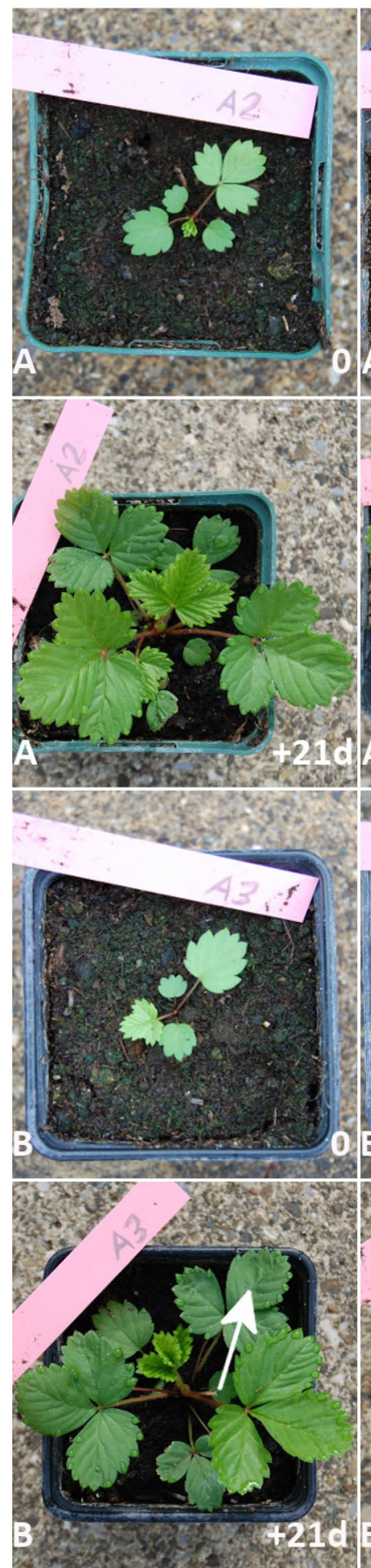

PA type S
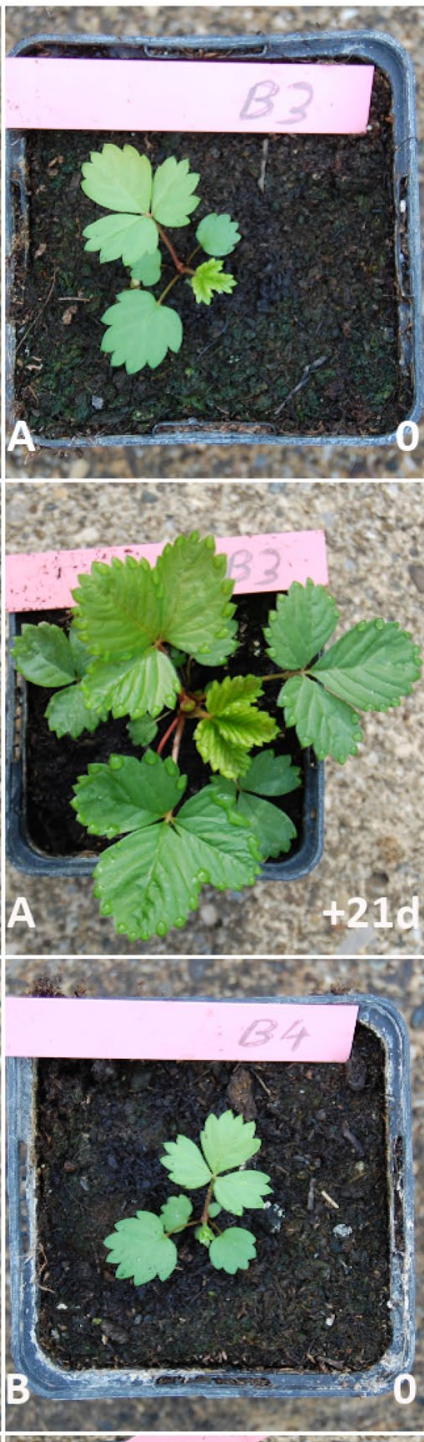

$\mathrm{H}_{2} \mathrm{O}$ type $\mathrm{T}$
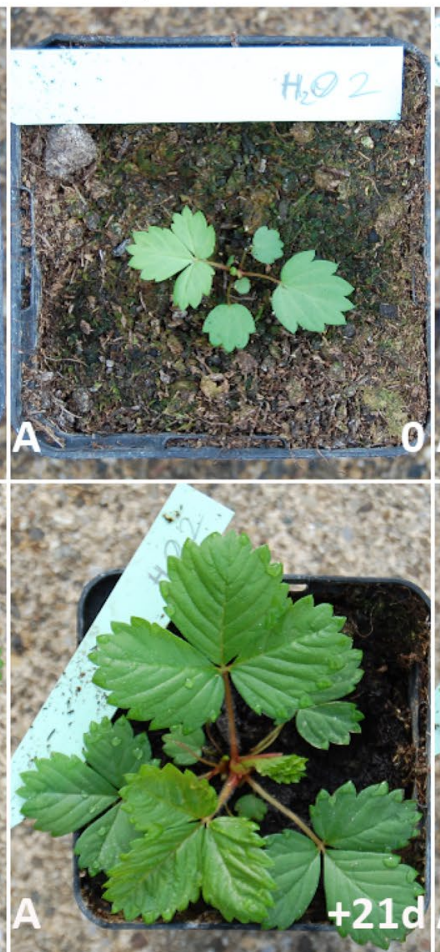

1
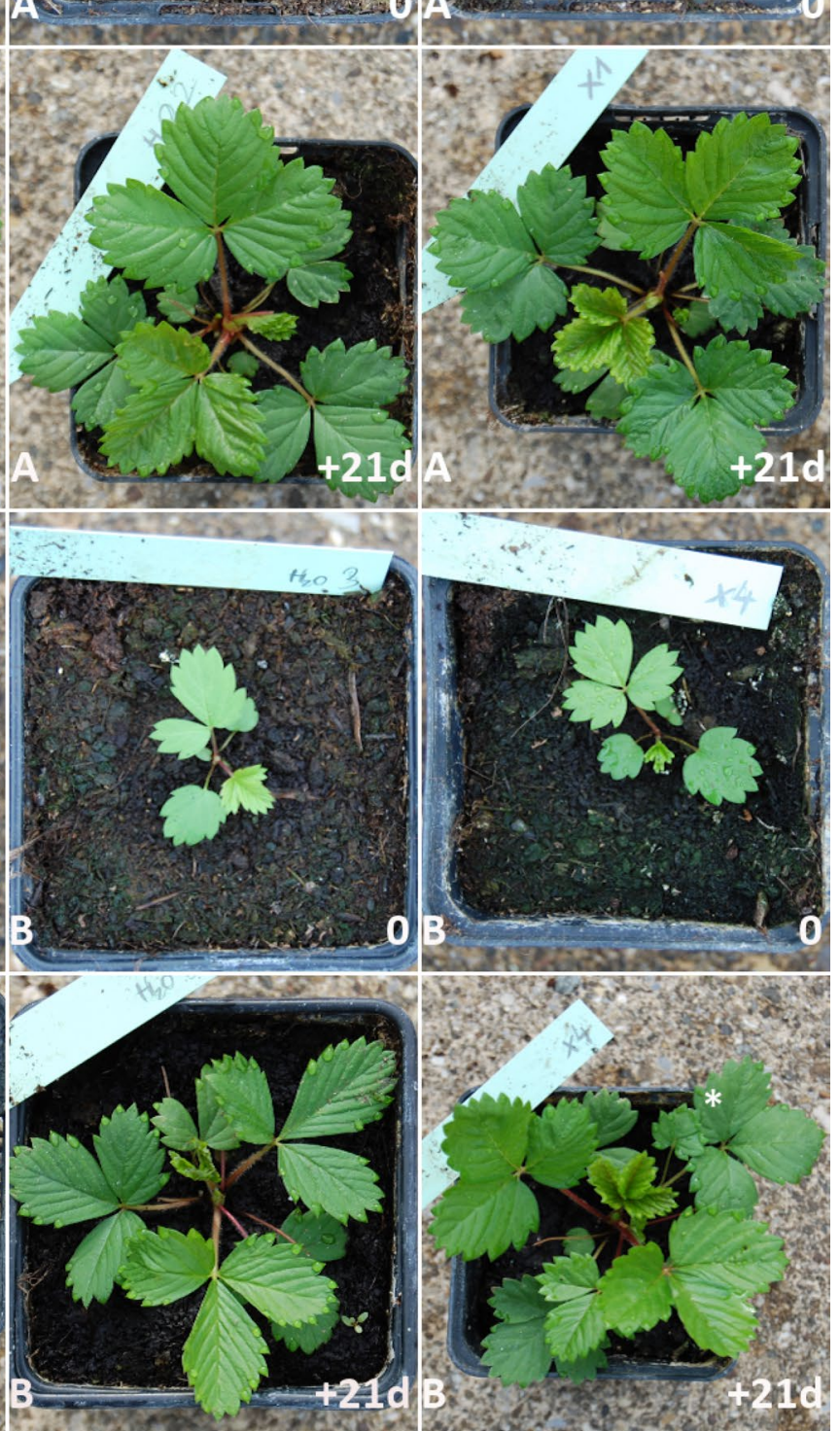

Fig. 6 PDI-plant compatibility assay on young Fragaia vesca plants outside. Two representative plants per treatment group as indicated with "A" and "B" at day zero indicated by "0" and 21 days after treatment start "+21d" are shown. Samples have been sprayed $(300 \mu \mathrm{l}$ from above) once (type $S$ ) or three times (type $T$ ) with Baypure DS
100 (PA) well as baseline control $\left(\mathrm{H}_{2} \mathrm{O}\right)$ and a completely untreated control (Co-/-). Slight leaf deformations are visible in the type T PA samples. Leaf damage sites or deformations are indicated by arrows. Pest damage indicated by asterisk 
Fig. 7 PDI-plant compatibility assay on young Fragaria vesca plants outside the greenhouse. Two representative plants per treatment group as indicated with "A" and "B" at day zero and (indicated by " 0 " and 21 days after treatment start "+21d" are shown. Samples have been sprayed (300 $\mu \mathrm{l}$ from above) three times (type $\mathrm{T}$ ) and once (type $S$ ) with $100 \mu \mathrm{M}$ $\mathrm{Chl}+1.2 \% \mathrm{PA}$ as well as a type T PA control. Observable leaf damage in the three times treated $\mathrm{Chl}+\mathrm{PA}$ samples as well as in the PA control. Arrows indicate leaf damage sites or deformations

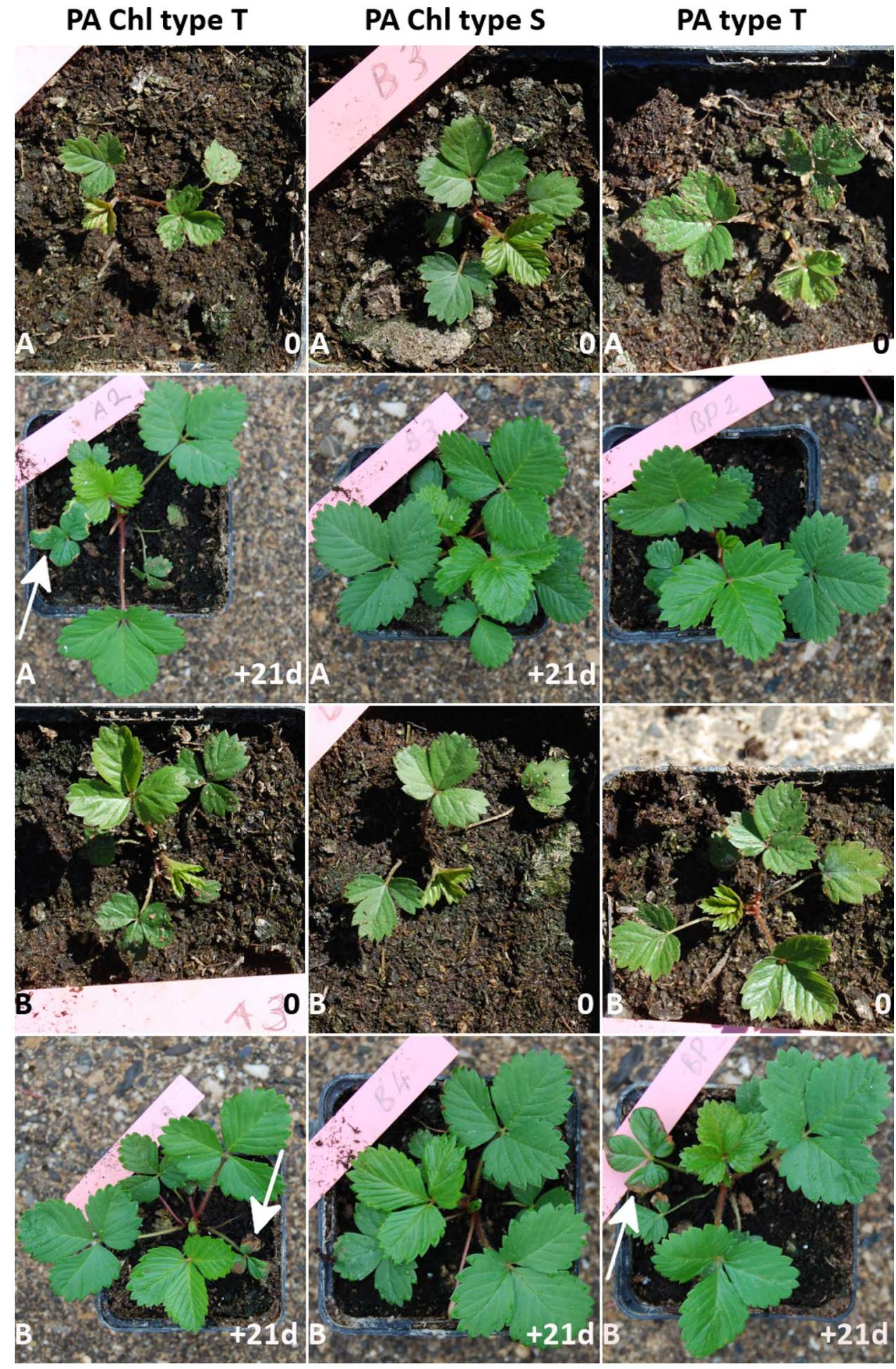

Increasing the chelation power by replacing $\mathrm{Na}_{2}$ EDTA with PA (Baypure DS 100®) induced minimal leaf deformations in the type $\mathrm{S}$ and $\mathrm{T}$ test groups (Fig. 6). However, this was also observed in the water and $\mathrm{Co}-/-$ groups. It is assumed that these leaf deformations may partly arise due to heat stress, osmotic/salt stress or lensing effects of dew or spray droplets, but could also be attributed to treating plants in a very early stage of development. Figure 7 shows a combination of PA with Chl (type $\mathrm{S}+\mathrm{T}$ ) and a PA control (type T). All four plants in the type T treatment group of PA + Chl showed leaf damage in the actually treated leaves indicated by arrows (necrosis, brown leaf margins, 
leaf deformations), but overall plant development was unaffected.

Only a very limited number of studies focus on Photodynamic Plant Protection. Fracarolli et al. [27] showed that sunlight activation of $50 \mu \mathrm{M} 8$-methoxypsoralen (8-MOP) was able to completely kill conidia of Colletotrichum acutatum conidia. They also tested the effects on the host plant leaves Citrus sinensis) and reported no observable damage to the citrus plants. Ambrosini et al., applied the anionic porphyrin Tetra-4-sulfonatophenyl porphyrin tetra-ammonium (TPPS) and were able to inhibit the mycelial growth of Botrytis cinerea at 1.5 $\mu \mathrm{M}$ PS concentration. They also were able to show in a trial with grapevine clones (Chardonnay, Merlot, Sauvignon), that $12.5 \mu \mathrm{M}$ TPPS has no adverse effect on grapevine roots. Botrytis cinerea on grapevine vs $-1.5 \mu \mathrm{M}$ TPPS was shown to completely inhibit mycelial growth [28]. Gonzales et al. [29] used 25 and $50 \mu \mathrm{M}$ Methylene blue and $30 \mathrm{~min}$ sunlight illumination to treat petals and leaves of sweet orange plants infected with conidia of Colletotricum abscissum and were able to obtain a $3 \log _{10}$ reduction-and complete eradication of conidia in some samples.

The results of these studies are very promising and show good efficacy of the photoactive substances at lower concentrations when compared to our experiments. However, as different model organisms, PS and experimental conditions were used, direct comparison is difficult. We achieved $94.1 \%$ growth inhibition of $A$. solani and $B$. cinerea after photoinactivation based on $100 \mu \mathrm{M} \mathrm{Chl}$ with $5 \mathrm{mM} \mathrm{Na}_{2}$ EDTA or complete killing of mycelial sheres with $100 \mu \mathrm{M} \mathrm{B} 17-0024$. For evaluation of these results, one must consider that the samples treated in this study are tissoid structures that might be more difficult to treat than single hyphae or conidia due to the need for the photosensitizers and activating light to penetrate the mycelial spheres.

Even though the killing efficiency is somewhat lower for Chl when compared to B17-0024, the natural origin of $\mathrm{Chl}$ might allow for an economic and eco-friendly application in agriculture (given a typical spraying volume of $2000 \mathrm{~L}$ per hectare in orchards and a concentration of the photoactive compound of $100 \mu \mathrm{M}, 137 \mathrm{~g}$ of $\mathrm{Chl}$ are needed). This aspect requires special consideration for more expensive photosensitizers such as TPPS or the ecologically more problematic phenothiazines.

In conclusion, Photodynamic Inactivation based on chlorin e6 derivatives adds to the grower's toolbox to fight plant diseases caused by fungal and bacterial [16] plant diseases. The synthetic B17-0024 shows somewhat higher photokilling efficiency when compared to $\mathrm{Chl}$. The natural compound, however, allows for economic and eco-friendly application. Both substances do not induce negative effects on the development of strawberry plants.

\section{Conclusion}

In face of expiring approvals for substances used in plant protection as well as the rising demand of organically farmed agricultural produce and considering the strict regulations regarding plant protection that come with it, PDI might emerge at exactly the right time to present an alternative approach for fighting fungal phytopathogens.

The data presented in this study prove that Photodynamic Inactivation based on two derivatives of chlorin e6 is a feasible tool to kill fungi relevant in agriculture in lab experiments. Considering the fact that the compounds will be applied in agricultural practice in high amounts, the use of Chl as PS should allow for economical and eco-friendly treatment, given its approval as food additive. The good water-solubility of $\mathrm{Chl}$ is also advantageous for this specific application, as the substances are typically applied in the field in aqueous solution.

However, to be effective against fungi and Gram-negative bacteria [16], addition of $\mathrm{Na}_{2}$ EDTA is required. As this additive does neither influence the absorption properties of Chl, nor the generation of ROS, the approach of combining a natural PS with a cell wall permeabilizer appears to be valid. As alternative PS, B17-0024 allows significant killing of both fungal species without additives and, at least for Alternaria, at a concentration one order in magnitude lower $(10 \mu \mathrm{M})$ when compared to $\mathrm{Chl}$ $(100 \mu \mathrm{M})$. Successful phototreatment of small mycelial spheres, as we demonstrate here, proves that both PS are able to diffuse into these mycelial structures to sensitize hyphae inside the spheres.

The experimental protocols based on either $\mathrm{Chl}+\mathrm{Na}_{2}$ EDTA or B17-0024 appear to be safe for plant leaves. Extension of plant compatibility testing, field trials as well as further fine-tuning of the PS/additive solutions are needed to ensure a successful transition of the technology from the lab into the farmer's toolkit. Hopefully, the model system introduced here for determination of photokilling of mycelial spheres and the plant compatibility assay based on young strawberries will serve as guide for future investigations and will help to encourage researchers involved in Photodynamic Inactivation to get involved in plant protection by photosensitizers and light.

Supplementary Information The online version contains supplementary material available at https://doi.org/10.1007/s43630-021-00157-0.

Acknowledgements The authors are grateful to Suncor Energy Inc., Mississauga Ontario, Canada for providing B17-0024 and for financial support.

Funding Open access funding provided by Paris Lodron University of Salzburg. 


\section{Declarations}

Conflict of interests The authors declare no competing interests.

Open Access This article is licensed under a Creative Commons Attribution 4.0 International License, which permits use, sharing, adaptation, distribution and reproduction in any medium or format, as long as you give appropriate credit to the original author(s) and the source, provide a link to the Creative Commons licence, and indicate if changes were made. The images or other third party material in this article are included in the article's Creative Commons licence, unless indicated otherwise in a credit line to the material. If material is not included in the article's Creative Commons licence and your intended use is not permitted by statutory regulation or exceeds the permitted use, you will need to obtain permission directly from the copyright holder. To view a copy of this licence, visit http://creativecommons.org/licenses/by/4.0/.

\section{References}

1. The World Bank. (2019). Arable land (hectares per person). Food and Agriculture Organization. Accessed Jun 2019.

2. United Nations. (2019). World population prospects 2019: Data booklet, United Nations Pubn. Accessed Jun 2019.

3. Kemmitt, G. (2013). Early blight of potato and tomato. The plant health instructor. Accessed Jun 2019.

4. Adhikari, P., Oh, Y., \& Panthee, D. (2017). Current status of early blight resistance in tomato: An update. International Journal of Molecular Sciences, 18(10), 2019. https://doi.org/10.3390/ijms1 8102019

5. Chaerani, R., \& Voorrips, R. (2006). Tomato early blight (Alternaria solani): The pathogen, genetics, and breeding for resistance. Journal of General Plant Pathology, 72, 335-347. https://doi.org/ 10.1007/s10327-006-0299-3

6. Boddy, L. (2016). Chapter 8-pathogens of autotrophs. The fungi (pp. 245-292). Academic Press.

7. European and Mediterranean Plant Protection Organization. (2004). Normes OEPP. EPPO Standards. Good plant protection practice. Bonne pratique phytosanitaire: Solanaceous crops under protected cultivation. EPPO Bulletin, Bd. 34, pp. 65-77.

8. European and Mediterranean Plant Protection Organization. (2004). Normes OEPP. In EPPO Standards. Good plant protection practice. Bonne pratique phytosanitaire: Outdoor Solanaceous crops. EPPO Bulletin, Bd. 34, Nr. 1, pp. 79-90.

9. Kuehne, S., Rossberg, D., Röhrig, P., Mehring, F. V., Weihrauch, F., Kanthak, S., Kienzle, J., Patzwahl, W., Reiners, E., \& Gitzel, J. (2017). The use of copper pesticides in Germany and the search for minimization and replacement strategies. Organic Farming, $3(1), 66-75$.

10. Wightwick, A. M., Reichman, S. M., Menzies, N. W., \& Allinson, G. (2013). Industry wide risk assessment: A case study of $\mathrm{Cu}$ in Australian Vineyard soils. Water Air Soil Pollution, 224, 12.

11. Lamichhane, J. R., Osdaghi, E., Behlau, F., \& Köhl, J. (2018). Thirteen decades of antimicrobial copper compounds applied in agriculture. A review. Agronomy for Sustainable Development., $38(3), 28$

12. Besnard, E., Chenu, C., \& Robert, M. (2001). Influence of organic amendments on copper distribution among particle-size and density fractions in Champagne vineyard soils. Environmental Pollution, 112(3), 329-337.

13. Miotto, A., Ceretta, C. A., Brunetto, G., Nicoloso, F. T., Girotto, E., Farias, J. G., Tiecher, T. L., De Conti, L., \& Trentin, G. (2013). Copper uptake, accumulation and physiological changes in adult grapevines in response to excess copper in soil. Plant and Soil, 2013, 593-610.

14. The European Commission. (2018). Commission Implementing Regulation (EU) 2018/1981 of 13 December 2018 renewing the approval of the active substances copper compounds, as candidates for substitution, in accordance with Regulation (EC) No $1107 / 2009$ of the European Parliament, Official Journal of the European Union.

15. Wainwright, M., Maisch, T., Nonell, S., Plaetzer, K., Almeida, A., Tegos, G. P., \& Hamblin, M. R. (2017). Photoantimicrobialsare we afraid of the light? The Lancet Infectious Diseases, 17(2), e49-e55. https://doi.org/10.1016/S1473-3099(16)30268-7

16. Glueck, M., Hamminger, C., Fefer, M., Liu, J., \& Plaetzer, K. (2019). Save the crop: Photodynamic Inactivation of plant pathogens I: Bacteria. Photochemical and Photobiological Sciences, 18(7), 1700-1708.

17. LeBel, C. P., Ischiropoulos, H., \& Bondy, S. C. (1992). Evaluation of the probe 2', 7'-dichlorofluorescin as an indicator of reactive oxygen species formation and oxidative stress. Chemical Research in Toxicology, 5(2), 227-231.

18. Hamminger, C. (2018). Combating environmental pathogens: Photodynamic Inactivation of Erwinia amylovora and Xanthomonas axonopodis by natural and natural-derivative photosensitizers and establishment of a plant compatibility assay on Fragaria vesca. University of Salzburg, Department of Biosciences, Master thesis.

19. Garrido, C., Carbu, M., Fernandez-Acero, F.J., Gonzalez-Rodriguez V.E., \& Cantoral, J.M. (2011). New insights in the study of strawberry fungal pathogens. In Husaini, A.M., and Mercado, J.A. (Eds), Genomics, transgenics, molecular breeding and biotechnology of strawberry, genes, genomes and genomics. (Vol. 5. pp. 24-39.) Japan: Global Science Books, Miki cho.

20. Hermann Meyer KG. (2020). Datenblatt Tonsubstrat ED 73. https://www.meyer-shop.com/pdf/products/814509A_DE.pdf. Accessed 29 Mar 2020

21. Gow, N. A. R., Latge, J.-P., \& Munro, C. A. (2017). The fungal cell wall: Structure, biosynthesis and function. Microbiology Spectrum, 5, 3. https://doi.org/10.1128/microbiolspec. FUNK-0035-2016

22. Luksiene, Z., \& Paskeviciute, E. (2011). Novel approach to the microbial decontamination of strawberries: Chlorophyllin-based photosensitization. Journal of Applied Microbiology, 110(5), 1274-1283. https://doi.org/10.1111/j.1365-2672.2011.04986.x

23. Buchovec, I., Lukseviciute, V., Marsalka, A., Reklaitisa, I., \& Luksiene, Z. (2016). Effective photosensitization-based inactivation of Gram (-) food pathogens and molds using the chlorophyllin-chitosan complex: Towards photoactive edible coatings to preserve strawberries. Photochemical and Photobiological Sciences, 15, 506-516. https://doi.org/10.1039/C5PP00376H

24. Alakomi, H. L., Paananen, A., Suihko, M. L., Helander, I. M., \& Saarela, M. (2006). Weakening effect of cell permeabilizers on gram-negative bacteria causing biodeterioration. Applied and Environment Microbiology, 72(7), 4695-4703. https://doi.org/10. 1128/AEM.00142-06

25. Sperandio, F. F., Huang, Y.-Y., \& Hamblin, M. R. (2013). Antimicrobial photodynamic therapy to kill gram-negative bacteria. Recent Patents on Anti-Infective Drug Discovery, 8(2), 108-120. https://doi.org/10.2174/1574891x113089990012

26. Meier, U., Graf, H., Hack, H., Hess, M., Kennel, W., Klose, R.,Mappes, D., Seipp, D., Stauss, R., Streif J., and Van den Boom, T. (2001). Growth stages of mono-and dicotyledonous plants. https://www.reterurale.it/downloads/BBCH_engl_2001. pdf. Accessed 29 Mar 2020.

27. Fracarolli, L., Rodrigues, G. B., Pereira, A. C., Massola Júnior, N. S., Silva-Junior, G. J., Bachmann, L., Wainwright, M., Kenupp Bastos, J., \& Braga, G. U. L. (2016). Inactivation of 
plant-pathogenic fungus Colletotrichum acutatum with natural plant-produced photosensitizers under solar radiation. Journal of Photochemistry and Photobiology B: Biology, 162, 402-411. https://doi.org/10.1016/j.jphotobiol.2016.07.009

28. Ambrosini, V., Issawi, M., Sol, V., \& Riou, C. (2020). Photodynamic inactivation of Botrytis cinerea by an anionic porphyrin: An alternative pest management of grapevine. Scientific Reports, 10, 17438. https://doi.org/10.1038/s41598-020-74427-9

29. Gonzales, C., Brancini, G. T. P., Rodrigues, G. B., Silva-Junior, G. J., Bachmann, L., Wainwright, M., \& Braga, G. U. L. (2017). Photodynamic inactivation of conidia of the fungus Colletotrichum abscissum on Citrus sinensis plants with methylene blue under solar radiation. Journal of Photochemistry and Photobiology B: Biology, 176, 54-61. https://doi.org/10.1016/j.jphotobiol.2017.09. 008

30. Huang, L., Xuan, Y., Koide, Y., Zhiyentayev, T., Tanaka, M., \& Hamblin, M. R. (2012). Type I and Type II mechanisms of antimicrobial photodynamic therapy: An in vitro study on gram-negative and gram-positive bacteria. Lasers in surgery and medicine, 44(6), 490-499. https://doi.org/10.1002/1sm.22045

31. Uliana, M. P., Pires, L., Pratavieira, S., Brocksom, T. J., de Oliveira, K. T., Bagnato, V. S., \& Kurachi, C. (2014). Photobiological characteristics of chlorophyll a derivatives as microbial PDT agents. Photochemical \&amp; photobiological sciences : Official journal of the European Photochemistry Association and the European Society for Photobiology, 13(8), 1137-1145. https:// doi.org/10.1039/c3pp50376c

32. Abrahamse, H., \& Hamblin, M. R. (2016). New photosensitizers for photodynamic therapy. The Biochemical Journal, 473(4), 347-364. https://doi.org/10.1042/BJ20150942 